\title{
Hubungan Tingkat Pendidikan, Pekerjaan, dan Paritas Ibu dengan Usia Penyapihan pada Balita
}

\author{
Vinda Dwi Oktoviyanda', Helwiyah Ropi ${ }^{2}$, Ai Mardhiyah ${ }^{2}$ \\ ${ }^{1}$ Fakultas Keperawatan Universitas Padjadjaran ${ }^{2}$ Fakultas Keperawatan Universitas Padjadjaran \\ E-mail: helwiyah_fik@yahoo.co.id
}

\begin{abstract}
Abstrak
Penyapihan cepat adalah salah satu penyebab anak terserang infeksi karena daya tahan tubuhnya menurun, namun ditemukan banyak ibu-ibu yang melakukan penyapihan cepat di Wilayah Posyandu "X". Penelitian ini bertujuan mengetahui hubungan antara tingkat pendidikan, pekerjaan, dan paritas ibu dengan usia penyapihan pada balita di Wilayah Posyandu X menggunakan metode deskriptif korelasional dengan studi retrospektif terhadap 60 responden ibu yang memiliki anak usia 2-5 tahun dengan tehnik purposive sampling dan dianalisis menggunakan spearman rank dan odd ratio (OR). Hasil penelitian menunjukkan tidak ada hubungan antara tingkat pendidikan dengan usia penyapihan $(p=0.868)$, ada hubungan negatif antara pekerjaan dengan usia penyapihan $(p=0.016)$ dan ada hubungan antara paritas dengan usia penyapihan $(p=0.027)$ serta nilai odd ratio (OR) 8,143. Dari hasil penelitian disarankan bahwa pendidikan kesehatan tentang ASI perlu ditambahkan tentang cara penyapihan ASI yang benar dan mengevaluasi pendidikan kesehatan yang diberikan secara teratur.
\end{abstract}

Kata kunci: Balita, paritas, pekerjaan, penyapihan ASI, tingkat pendidikan.

\section{The Correlation between the Level of Education, Job Status, Maternal Parities and the Weaning Time in Toddlers}

\begin{abstract}
The early weaning process is one of the infection causes among children. That process have influenced in reducing the children's immune. However, many mothers in the "Posyandu X" have applied the early weaning process to their children. This study aimed to know the relationship between the level of education, job status, maternal parities and the weaning time in toddlers in the "Posyandu X". This study used the descriptive correlational approach with retrospective study. Samples were 60 mothers who have children aged 2-5 years old. Samples were chosen using the purposive sampling method, and data were analysed using spearman rank and odd ratio (OR). The result showed that there were no correlation between the level of education and the age of weaning $(p=0.868)$, there were negative correlation between mother's job status and the age of weaning $(p=0.016)$, and there were correlation between the maternal parity and the age of waning $p=0.027$ ). The study also found that the odd ratio $=8.143$. The study suggests that the health education program related to breast feeding should involve the weaning process as part of the health education material.
\end{abstract}

Key words: Job status, parities, the level of education, the weaning process, toddlers. 
Vinda Dwi Oktoviyanda: Hubungan Tingkat Pendidikan, Pekerjaan, Paritas Ibu

\section{Pendahuluan}

Pemberian Air Susu Ibu (ASI) merupakan intervensi kesehatan yang paling aman, efisien, dan efektif untuk meningkatkan kesehatan anak. Hal tersebut sejalan dengan tujuan keempat The Millennium Development Goal (MDG4) tahun 2015 yaitu menurunkan kematian anak (Yusria, 2011). ASI merupakan sumber nutrisi terbaik dan terlengkap bagi bayi serta berperan dalam pertumbuhan yang cepat dan sehat dari otak, sistem persarafan, sistem pencernaan, dan perkembangan sistem kekebalan bayi (Simkin, Penny; Whalley, dkk. 2007).

World Health Organization (WHO) merekomendasikan ibu untuk memberikan ASI eksklusif selama enam bulan, setelah enam bulan diberikan makanan pendamping ASI secara benar dan tepat, dan ASI tetap diberikan sampai anak usia dua tahun atau lebih serta melakukan penyapihan setelah anak berusia dua tahun. Penyapihan berasal dari kata menyapih. Menyapih adalah menghentikan pemberian ASI kepada anak. Masa penyapihan merupakan masa yang paling kritis dalam kehidupan anak (Depkes RI, 1998). Usia penyapihan didefinisikan sebagai usia anak saat berhenti menyusu secara sempurna (Singh \& Singh, 2011).

Menurut data WHO tahun 2005 penyebab kematian balita terbesar di Indonesia adalah diare $18 \%$, pneumonia $14 \%$, dan campak 5\% (Aklima, 2009). Salah satu penyebab terjadinyapenyakittersebutadalahpenyapihan cepat. Richards (2011) menyatakan bahwa penyapihan cepat mengakibatkan daya tahan tubuh anak menurun karena perlindungan terhadap infeksi dan kesakitannya rendah. Bayi yang tidak diberikan ASI secara penuh memiliki risiko 2,23 kali lebih tinggi untuk terserang Infeksi Saluran Pernapasan Akut (ISPA) dan diare (Aklima, 2009).

Beberapa penelitian telah dilakukan untuk mengidentifikasi faktor yang memengaruhi usia penyapihan, yaitu faktor sosiodemografi (usia, tempat tinggal, tingkat pendidikan, status pernikahan, paritas, pekerjaan, dan pendapatan) dan faktor psikososial (niat menyusui, keyakinan pada kemampuan menyusui, dan dukungan sosial) (Yusria, 2011). Faktor sosio-demografi lebih memengaruhi keputusan ibu untuk berhenti menyusui dibandingkan dengan faktor psikososial yang justru lebih berpengaruh pada peran ayah terhadap keputusan ibu untuk berhenti menyusui (Marcil, 2005). Faktor sosio-demografi (sosial ekonomi dan demografi) seperti paritas, tempat tinggal, tingkat pendidikan, dan pekerjaan ibu merupakan faktor yang berpengaruh terhadap usia penyapihan (Singh \& Singh, 2011).

Semakin tinggi tingkat pendidikan ibu, maka semakin cepat usia penyapihannya karena ibu dengan tingkat pendidikan tinggi kemungkinan memberikan makanan tambahan kepada anak lebih cepat sehingga durasi menyusuinya lebih pendek (Singh \& Singh, 2011). Selain itu, Akter \& Rahman (2010) menyatakan bahwa salah satu pengaruh menurunnya praktik menyusui disebabkan oleh meningkatnya tingkat pendidikan ibu, faktor yang berperan dalam adopsi pemikiran modern dalam merawat anak, dan pendidikan mewakili status sosial ekonomi yang berhubungan dengan mudahnya terpengaruh oleh iklan dan kemampuan membeli susu formula.

Ibu yang bekerja tidak memiliki waktu yang cukup untuk menyusui anaknya selama bekerja sehingga memilih untuk menyapih anaknya lebih cepat dan memberikan makanan tambahan lebih cepat (Singh \& Singh, 2011). Sama halnya dengan yang diungkapkan oleh Haroun, Mahfouz, dan Ibrahim (2008) bahwa ibu yang bekerja memiliki waktu yang lebih cepat untuk melakukan penyapihan karena ibu tidak memiliki cukup waktu untuk menyusui selama bekerja.

Semakin tinggi paritas ibu maka semakin lambat usia penyapihan yang dilakukan. Hal tersebut mengacu pada fakta bahwa ibu dengan paritas tinggi memiliki usia lebih tua dan memproduksi ASI lebih sedikit. Selain itu, interval kelahiran yang rendah dan waktu yang singkat untuk menyusui mengakibatkan ibu melakukan penyapihan cepat (Singh \& Singh, 2011).

Berdasarkan data yang didapatkan dari Dinas Kesehatan Kabupaten Bandung tahun 2011, jumlah kasus ISPA pada anak usia 1-4 tahun sebanyak 29.852 kasus, sedangkan jumlah kasus diare pada tahun 2011 sebanyak 71.010 kasus. Adapun data dari Puskesmas "X" menunjukkan jumlah kejadian ISPA bukan pneumonia tahun 2012 berjumlah 
Vinda Dwi Oktoviyanda: Hubungan Tingkat Pendidikan, Pekerjaan, Paritas Ibu

2.458 kasus menyerang anak usia dua bulan sampai empat tahun. Sementara itu, kejadian diare pada bulan Mei dan Juni 2012 sebanyak 53 kasus menyerang anak usia nol hingga empat tahun.

Hasil studi pendahuluan pada 12 orang ibu didapatkan enam anak disapih pada usia $<2$ tahun dengan alasan ibu kembali bekerja dan alasan kehamilan, sedangkan enam anak lainnya disapih pada usia $\geq 2$ tahun. Adapun tujuan umum dari penelitian ini adalah untuk mengetahui hubungan tingkat pendidikan, pekerjaan, dan paritas ibu dengan usia penyapihan pada balita di Wilayah Posyandu "X".

\section{Metode Penelitian}

Rancangan penelitian yang digunakan adalah deskriptif korelasional dengan studi retrospektif. Variabel terikatnya adalah usia penyapihan dan variabel bebasnya yaitu tingkat pendidikan, pekerjaan, dan paritas ibu. Adapun populasi dalam penelitian ini adalah ibu yang memiliki anak usia 2-5 tahun di wilayah Posyandu $\mathrm{X}$ yang berjumlah 66 orang dengan menggunakan teknik purposive sampling dengan kriteria inklusi (ibu yang melakukan penyapihan) dan kriteria eksklusi (Ibu yang tidak menyusui anaknya) didapatkan sampel 60 responden. Instrumen yang digunakan dalam penelitian ini adalah kuesioner yang dibuat sendiri oleh peneliti dengan jenis kuesioner tertutup dan terbuka dan telah dilakukan uji validitas isi kepada ahli.

\section{Hasil Penelitian}

Dalam hasil penelitian ini menunjukkan gambaran tingkat pendidikan, pekerjaan, paritas, dan usia penyapihan yang dapat dilihat pada tabel 1. Berdasarkan tabel tersebut menunjukkan bahwa sebagian besar dari respoden $(53,3 \%)$ memiliki pendidikan tinggi, sebagian besar responden (70\%) tidak meninggalkan rumah selama $>4$ jam setiap harinya $(70 \%)$, sebagian besar responden $(76,7 \%)$ merupakan ibu multipara, dan sebagian dari responden $(56,7 \%)$ melakukan penyapihan cepat. Hasil penelitian hubungan antara tingkat pendidikan ibu dengan usia penyapihan di wilayah posyandu $\mathrm{X}$ dapat dilihat pada tabel 2.

Data pada tabel 2 menunjukkan $p$ value sebesar 0.858 yang nilainya lebih besar dari nilai $\alpha=0.05$, yang berarti bahwa secara statistik tidak terdapat hubungan antara tingkat pendidikan dengan usia penyapihan. Adapun hasil penelitian hubungan pekerjaan ibu dengan usia penyapihan pada balita di Wilayah Posyandu X dapat dilihat pada tabel 3.

Data tabel 3 menunjukkan $p$ value sebesar 0.016 yang mana lebih kecil dari nilai $\alpha=$ 0.05 , dan keeratan korelasi yang terjadi pada variabel tersebut sebesar -0.309 . Berdasarkan analisis tersebut dapat disimpulkan bahwa pekerjaan ibu memiliki hubungan negatif

Tabel 1 Usia Penyapihan pada Balita Usia 2-5 Tahun di Wilayah Posyandu X (n=60)

\begin{tabular}{lcc}
\hline \multicolumn{1}{c}{ Subvariabel } & $\boldsymbol{f}$ & $\mathbf{\%}$ \\
\hline Tingkat Pendidikan & & \\
Rendah & 28 & 46,7 \\
Tinggi & 32 & 53,3 \\
Pekerjaan & & \\
Bekerja & 18 & 30,0 \\
Tidak Bekerja & 42 & 70,0 \\
Paritas & & \\
Primipara & 14 & 23,3 \\
Multipara & 46 & 76,7 \\
Usia Penyapihan & & \\
Cepat & 34 & 56,7 \\
Tepat & 26 & 43,3 \\
\hline
\end{tabular}


Vinda Dwi Oktoviyanda: Hubungan Tingkat Pendidikan, Pekerjaan, Paritas Ibu

Tabel 2 Tingkat Pendidikan Ibu dengan Usia Penyapihan pada Balita di Wilayah Posyandu X Tahun 2012

\begin{tabular}{lccl}
\hline \multirow{2}{*}{ Sub Variabel } & \multicolumn{2}{c}{ Usia Penyapihan } & \multirow{2}{*}{$\boldsymbol{P}$} \\
\cline { 2 - 3 } & $\mathbf{( \% )}$ & $\mathbf{( \% )}$ & \\
\hline Tingkat Pendidikan & Cepat & Tepat & 0.858 \\
Rendah & 28,3 & 18,3 & \\
Tinggi & 28,3 & 25 & \\
\hline
\end{tabular}

yang rendah dengan usia penyapihan, sehingga ibu tidak bekerja melakukan penyapihan lebih cepat.

Hasil penelitian mengenai hubungan paritas ibu dengan usia penyapihan pada balita di Wilayah Posyandu X dapat dilihat pada tabel 4. Data pada tabel 4 menunjukkan $p$ value sebesar 0.027 yang mana lebih kecil dari nilai $\alpha=0.05$, dan hubungan korelasi yang terjadi pada variabel tersebut sebesar 0.286, serta nilai OR didapatkan sebesar 8,143 yang berarti paritas ibu memiliki faktor resiko 8,143 kali terhadap usia penyapihan. Dapat disimpulkan bahwa paritas ibu memiliki hubungan yang rendah dengan usia penyapihan dan ibu multipara memiliki resiko 8,143 kali untuk melakukan penyapihan cepat dibandingkan dengan ibu primipara.

\section{Pembahasan}

Gambaran tingkat pendidikan ibu menunjukkan banyaknya responden dengan tingkat pendidikan tinggi, hal ini akan berdampak pada praktik penyapihan yang baik karena menurut Sadiman (2009), ibu dengan tingkat pendidikan yang lebih tinggi lebih menyadari keuntungan menyusui, banyak membaca literature sehingga lebih termotivasi untuk menyusui. Berbeda dengan pendapat Siregar (2004) yang mengatakan bahwa kesehatan status gizi pada bayi/anak serta kelangsungan hidupnya akan lebih baik pada ibu yang berpendidikan rendah karena ibu dengan pendidikan tinggi akan memiliki pengetahuan luas serta kemampuan untuk menerima informasi lebih tinggi sehingga berkeinginan untuk hidup modern dari pengaruh iklan pengganti ASI sehingga berniat mengganti ASI dengan susu formula.

Gambaran pekerjaan ibu menunjukkan sebagian besar ibu tidak bekerja. Menurut peneliti, banyaknya ibu yang tidak bekerja dapat berpengaruh terhadap praktik penyapihan yang baik karena Singh (2011) menyatakan bahwa ibu yang bekerja tidak memiliki banyak waktu untuk menyusui bayi mereka karena mereka bekerja di luar sehingga memilih untuk menyapih anaknya lebih cepat. Selain itu, Akter dan Rahman (2010) menyatakan bahwa jenis pekerjaan memengaruhi proses penyapihan. Pekerjaan informal atau tradisional seperti pertanian, pekerjaan domestik, industri, wiraswasta, dan buruh memiliki waktu yang fleksibel dan hal ini memberikan waktu untuk mengasuh anaknya termasuk menyusui sehingga usia penyapihannya bisa lebih lambat.

Gambaran paritas ibu menunjukkan bahwa sebagian besar ibu merupakan ibu multipara. Secara teori, produksi ASI akan menyesuaikan kebutuhan bayi dan produksi ASI pada

Tabel 3 Hubungan antara Pekerjaan Ibu dengan Usia Penyapihan pada Balita di Wilayah Posyandu X Tahun 2012

\begin{tabular}{lcccc}
\hline \multirow{2}{*}{ Sub Variabel } & \multicolumn{2}{c}{ Usia Penyapihan } & Koefisien \\
\cline { 2 - 5 } & $\mathbf{( \% )}$ & $\mathbf{( \% )}$ & Korelasi \\
\hline Pekerjaan & Cepat & Tepat & & -0.309 \\
Bekerja & 11,7 & 16,7 & 0.016 & \\
Tidak Bekerja & 45 & 26,7 & & \\
\hline
\end{tabular}


Vinda Dwi Oktoviyanda: Hubungan Tingkat Pendidikan, Pekerjaan, Paritas Ibu

Tabel 4 Hubungan antara Paritas Ibu dengan Usia Penyapihan pada Balita di Wilayah Posyandu X Tahun 2012

\begin{tabular}{|c|c|c|c|c|c|}
\hline \multirow{2}{*}{ Sub Variabel } & \multicolumn{2}{|c|}{ Usia Penyapihan } & \multirow{3}{*}{$P$} & \multirow{3}{*}{$\begin{array}{c}\text { Koefisien } \\
\text { Korelasi }\end{array}$} & \multirow{3}{*}{ OR } \\
\hline & $(\%)$ & $(\%)$ & & & \\
\hline Paritas & Cepat & Tepat & & & \\
\hline Primipara & 16,7 & 6,7 & \multirow{2}{*}{0.027} & \multirow{2}{*}{0.286} & \multirow{2}{*}{8,143} \\
\hline Multipara & 38,3 & 38,3 & & & \\
\hline
\end{tabular}

ibu multipara lebih banyak dibandingkan dengan ibu primipara (IDAI, 2009) sehingga menurut peneliti seharusnya ibu multipara dapat melakukan penyapihan secara tepat karena produksi ASI nya lebih banyak. Akter dan Rahman (2010) mengatakan bahwa ibu multipara dikaitkan dengan durasi menyusui yang lebih pendek, hal ini mengarah pada jarak kelahiran yang pendek dan waktu yang singkat sehingga tuntutan waktunya untuk mengurus anak memengaruhi ibu untuk melakukan penyapihan lebih cepat.

Hal ini menunjukkan bahwa usia penyapihan yang dilakukan oleh ibu di Wilayah Posyandu $\mathrm{X}$ tidak sesuai dengan anjuran WHO yang merekomendasikan wanita menyusui sampai usia anak dua tahun dan Baskoro (2008) yang menyatakan bahwa usia dua tahun merupakan usia ideal untuk anak dilakukan penyapihan.

Dukungan sosial kemungkinan memiliki pengaruh terhadap usia penyapihan. Shahla, Fahy, \& Kable (2010) mengatakan bahwa dukungan sosial untuk menyusui tampak efektif, wanita yang memilih untuk menyusui anaknya merasa dukungan sosialnya lebih kuat serta dukungan dari pasangan dan masyarakat secara umum berpengaruh penting dalam keberhasilan menyusui.

Dalam penelitian ini tidak dilakukan analisis mengenai niat ibu untuk menyusui, breastfeeding self-efficacy, dan dukungan sosial sehingga disarankan bagi penelitian selanjutnya untuk mengidentifikasi mengenai hubungan niat ibu menyusui, breastfeeding self-efficacy, dan dukungan sosial dengan usia penyapihan agar dapat terlihat pengaruh hal tersebut terhadap usia penyapihan yang dilakukan.

\section{Simpulan}

Penelitian ini merupakan penelitian kuantitatif tentang Hubungan Tingkat Pendidikan,
Pekerjaan, dan Paritas Ibu dengan Usia Penyapihan pada Balita . Berdasarkan hasil penelitian dan pembahasan dapat disimpulkan bahwa tidak terdapat hubungan antara tingkat pendidikan ibu dengan usia penyapihan $(p=0.868)$, Ada hubungan negatif antara pekerjaan ibu dengan usia penyapihan $(p=0.016)$ dan koefisien korelasi $(-0.309)$, yang berarti ibu yang tidak bekerja melakukan penyapihan lebih cepat. Hal ini kemungkinan disebabkan oleh berbagai faktor. Terdapat hubungan yang rendah antara paritas ibu dengan usia penyapihan $(p=0.286)$, dan berdasarkan hasil perhitungan OR menunjukkan ibu multipara beresiko 8,143 kali melakukan penyapihan cepat dibandingkan dengan ibu primipara.

Berdasarkan hasil penelitian diatas, pihak puskesmas disarankan untuk melakukan evaluasi mengenai pemberian penyuluhan kesehatan mengenai ASI, menyusui, dan menyapih kepada ibu yang sedang hamil dan menyusui. Selain itu, pemberian penyuluhan mengenai manfaat menyusui dan dampak penyapihan cepat yang dapat mengakibatkan perlindungan terhadap berbagai infeksi dan kesakitannya rendah sehingga anak mudah sakit dan terserang infeksi. Bagi penelitian selanjutnya diharapkan dapat melakukan penelitian mengenai penyapihan dengan variabel yang lain seperti faktor psikososial.

\section{Daftar Pustaka}

Aklima. (2009). Hubungan penyapihan dini dengan kejadian ISPA pada anak usia 12-18 bulan di Kota Padang. Yogyakarta: Program Pascasarjana Fakultas Kedokteran Universitas Gadjah Mada.

Akter, S. \& Rahman, M.M. (2010). Duration of beastfeeding and its correlates in Bangladesh. Journal Health Population Nutrition, 595-601. 
Vinda Dwi Oktoviyanda: Hubungan Tingkat Pendidikan, Pekerjaan, Paritas Ibu

Baskoro, A. (2008). ASI panduan praktis ibu menyusui. Yogyakarta: Banyu Media.

Depkes RI. (1998). Tuntutan praktis bagi tenaga gizi puskesmas bekalku membina keluarga sadar gizi. Jakarta: Bina Kesehatan.

Haroun, H.M., Mahfouz, M.S., \& Ibrahim, B.Y. (2008). Breastfeeding indicators in Sudan: a case study of wad medani town. Sudanese Journal of Public Health, 81-90.

IDAI. (2009). Ikatan dokter anak Indonesia. Diakses dari http://www.idai.or.id/asi/ arTikel.asp?q=2012105101143.

Marcil, L. (2005). Psychosocial factors and duration of breastfeeding among women in Denmark. CIS, 11, 495.

Richards, A. (2011). Live strong. Diakses dari http://www.livestrong.com/article/1439problems-stoppong-breastfeeding.

Sadiman. (2009). Determinan ibu melakukan penyapihan pada anak kurang dari dua tahun di puskesmas Yosomulyo Kota Metro. Jurnal Kesehatan Metro Sai Mawai, 41.

Shahla, M., Fahy, K., \& Kable, A.K.
(2010). Factors that possitively influence breastfeeding duration to 6 months: A literature review. EPublications Southern Cross University .

Simkin, P., Whalley, J., \& Keppler, A. (2007). Panduan lengkap kehamilan, melahirkan, dan bayi. Jakarta: Arcan.

Singh, N. S. (2011). Determinants of breastfeeding amongst women in Manipur. Bangladesh Journal of Medical Science, 10(4).

Simkin, P. (2007). The birth partner: A complete guide to childbirth for dads doulas, and all other labor companions. 3rd ed. Boston: Harvard Common Press.

Siregar, A. (2004). Faktor-faktor yang memengaruhi pemberian ASI oleh ibu melahirkan. (Skripsi). Fakultas Kesehatan Masyarakat Universitas Sumatera Utara, Medan.

Yusria. (2011). Pengaruh dukungan keluarga pada ibu dalam meningkatkan durasi menyusui sampai dengan usia 6 bulan di kota Langsa. Yogyakarta: Program Pascasarjana Fakultas Kedokteran UGM. 